\title{
DULEBOVA IRINA,
}

PhD, Associate Professor at the Department of Russian and East European Studies, Faculty of Arts, Comenius University, Bratislava, Slovakia

KOVALSKYI HRYHORII,

PhD in Philosophical Sciences, Associate Professor, Vasyl' Stus Donetsk National University, Vinnytsia, Ukraine

DODONOVA VIRA,

Doctor of Philosophical Sciences, Professor,

Borys Grinchenko Kyiv University, Ukraine

BILETSKY VITALIY,

PhD in Philosophical Sciences, Associate Professor,

Vasyl' Stus Donetsk National University, Vinnytsia, Ukraine

\section{WAR AND PEACE: WAYS TO PEACE IN WAR IN THE EASTERN UKRAINE ${ }^{1}$}

\begin{abstract}
The paper discloses the concept of "war" and "peace" in historiography from the position of (non-)violence methodology, conflictology, paxology, polemology, geophilosophy etc. It is approved that from the very beginning for peace making the methodology and terminology of paxology as peace theory should be used rather then the methodology and terminology of polemology as war theory. The specific of hybrid war is disclosed, hybrid forms of settling of deformed value orientations, substitution of senses, forming of deformed social and cultural, on the back of which spread conflict in the Eastern Ukraine, are shown. Algorithm of solution to the Eastern Ukrainian conflict is formulated, ways of negotiation of endogenous and exogenous crisis phenomena in the Eastern Ukraine in the form of "road map" is proposed.
\end{abstract}

Key words: the theory of peace; paxology; the theory of war; polemology; information warfare; hybrid war; war of meanings.

Problem definition. Scientific and technological progress over the last centuries caused impetuous transformations of social system and international communication methods, among which into the first place move armed conflicts. Technical means of confrontation change pattern and objects of war. In total, the history of humanity is the form of intercivilizational contacts that do not make possible self-isolation of states and separate nations, not always peaceful. Wars not only become a factor of destruction of established social life, but also can help in restoration of world community balance. Military technologies became a factor of speeding up of technological progress.

Considering these facts, removal of war phenomenon from social space and achievement of eternal peace is utopian idea. "If you want peace, study war" [Bouthoul, 2006] - this thought of polemologist G. Bouthoul appears to be true. In view of polemology war is the most effective form of interaction between nations and acts as a factor of culture interpenetration in historical aspect of social changes. The war originate the history as a chronicle of military conflicts. Considering the war as a disease of society, polemologists try to find methodology of peace-making and international safety system ensuring. Therefore, polemology faces the problem field of paxology as peace theory [Ковальський, 2018a]. In methodological plan, it is more advisable to use terminology of paxology, as far as it is aimed at the peace restoration from the very beginning.

The goal of the paper is to make a search of ways of restoring peace to the Eastern Ukraine and the best variant of resumption of Donetsk and Luhansk citizenship to social and cultural space of Ukraine.

Analysis of recent studies and publications. Peace theory studies predominantly occur within the context of (non-)violence methodology, conflictology, paxology, polemology, geophilosophy etc. I. Kant [Кант, 1994] rose the question on moral aspects of war and peace, emphasizing that existence of formidable army of one country would certainly cause a desire of other countries to have more powerful army. Therefore, the moral is an essential part of a route to peace. Considering interdisciplinarity, axiological and social aspects of the theory, it appears that an investigation of the conflict itself in which peace is merely war avoidance, public good conditions formation and social justice establishment method, is a methodological feature of "peace" concept. For further researches of "peace" phenomenon J. Galtung created International Peace Research Institute, scientists of which 1 The paper is written by the results of implementation of project "Social and philosophical reflection of ways of conflict solving in the
Eastern Ukraine" (official registration №: 0116U002518). 
developed a theory of peace making by means of prevention of war. Researches of "peace" concept with hollowing formulation of paxological conception scientists direct to the mental changes of these processes understanding, transition to positive vision of peace making, making a friend from a foe, or achievement of impersonal posture to oneself.

Substantial contribution to the Ukrainian paxology development are scientific works of study group of Vasyl' Stus Donetsk National University members of which are philosophers and sociologists from Ukraine and Poland. Sequence of publications of V. Struhatskyi [Стругацький, 2018, 2018a, 2017, 2016, 2016a], V. Hurzhy [Гуржи, 2017], R. Dodonov [Додонов, 2018, 2017, 2016, 2016a, 2016б, 2015, 2015a, 20156], V. Dodonova [Додонова, 2015], H. Kowalskyi [Ковальський, 2018, 2018a, 2017, 2016], M. Kolinko, V. Mandragelia [Мандрагеля, 2003], K. Novikova [Гібридна війна, 2017], L. Roman [Гібридна війна, 2017], R. Khalikov [Халіков, 2015], A. Shtokvish [Штоквиш, Короленко, 2015] illuminate peace in the Eastern Ukraine via different manifestations of counter an aggressor.

Consideration of "war" and "peace" concepts through the prism of natural human qualities, minds and formed psy-space, is a current trend of peace theory. Thus, O. Basaluk lays geophilosophy methodology, including methods of political philosophy, culturology, ethnology, economy, geography, neurophysics, psychology and social philosophy, as the foundation for methodological basis of his peace and war theory. The state of peace as method of locus enhancement with the purpose of need gratification of psy-space is more advantageous and comfortable selection variant for psy-space. Provided by peaceful widening of locus capabilities mutually advantageous integration and cooperation of psy-spaces happens, the amount of aggressively inclined minds decreases, the amount of aimed at integration and cooperation minds increases. Over the last century scientists observe war and peace complicating the mind structure and functions what results in changes of qualitative composition of the Earth psy-space in all of its aspects [Базалук, 20166].

Presentation of the basic material. Over the last years, Ukraine is in the throes of development problems as from declaration of independence. Our country is caught up among such countries worldwide that for the first time ever encountered a problem of establishing defenses under the conditions of information society. Information and psychological influence became prime factor of modern warfare, which was named "hybrid war". Today hybrid war is not new, but actual form of warfare expressed not only in the military field. "Hybrid" term denotes usage of all means and methods of pressure to the opponent among which military operations are of minor importance.

Conflict that presently spread in the Eastern Ukraine had several developmental stages: political infighting in Kyiv stemmed from violation of civil rights; civil opposition warmed up by external forces that gave occasion to maintaining an anti-terrorist operation; battle actions called war because of large scale, involved resources and presence of enemy troops on Ukrainian territory, where on one side is Russian Federation as an aggressor, on the other side is our country on the defense [Ковальський, 2018]. Research into the causes of appearance of such stages is necessary to search for military confrontation de-escalation mechanism and relevant instrumentation. Conflict transformation to the civil stage or political stage would turn off final processes of Ukrainian society schismogenesis. Without throwing away ephemeral conceptualization of the conflict, understanding of the actual situation of military paradigm, relevant decision making in military and political fields with a view to stop military operations, politic processes on territories under occupation are impossible just as protection of human and civil rights.

Nowadays a significant part of Ukrainian psy-space is kept under pressure of Russian propaganda that become possible due to hybrid aggression, and on the east of Ukraine warfare is conducted with the use of modern military technologies from arms - rocket artillery, to informational - signals intelligence station. Use of neoimperialist propaganda became some sort of trademark for aggressor because of the fact that this particular kind of weapons was the most powerful in local conflicts in Chechnya, South Ossetia, Abkhasia, where ground for bringing regular troops was prepared through impacts on morals and mental condition of people.

If the locus in perception of psy-space moved from geographical territory to the world of historical ideas, it would become sacramental and invincible. Aggressor of psy-space may occupy the territory, control resources and propagate its own ideology. However, until the world of historical ideas of victim's psy-space stay sacramental, it will be undefeated. In other words, not territory occupation, but successful obtrusion of own worldviews and system of values is the road to victory in modern conflicts [Базалук, 2016a].

Unfortunately, this axiomatic for XXI century thesis is often complained by very same people who reach political decisions. Illusions of the possibility of the Eastern Ukraine conflict resolution under military duress appeared many times on both sides. Leaving behind that "history doesn't like the subjunctive mood" modern "analytics" prefer reflecting in social networks how situation could evolve if politicians of both sides did not interfere in warfare and did not deter forces [Додонов, 2016a]. As an argument used by followers of militarized version of the Eastern Ukraine conflict resolution comes out the example of Croatia, where peace was established after decisive military attack and cleaning-up the grounds from separatists.

At the same time, military methods stay one of the most important factors that cannot be neglected when analyzing the conflict. "The power as a political factor, - pointed out M.V. Popovich, - is definitely not an abstraction. It is the possibility of real actions that depend on money, natural resources, army and fleet, discipline and allegiance of people etc. More power has the one who has more possibilities. That is exactly why the history unfolds twice: in real activity of people and institutes and in the world of their possibilities disclosed by these activities. Appearance and disappearance of "possible worlds" in consequence of act defines this act. In politics all is used for intimation, encouragement or menace, symbol of something totally different from that is spoken directed - all has indirect and symbolic meaning. Political space is relative and has its own semantics or number of semantics, several possible interpretations as a formal system" [Попович, 2005].

So, power policy and fixation on direct influence on human behavior by enforcement has nature limitations. Specificity of social relations control lies in the fact that influence on social behavior can be both immediate and direct. That is why when considering causes of the armed conflict in the Donbas should be taken into account not only military factors, but also geopolitical, (anti)oligarchic, independent, (anti-)Soviet, post-colonial aspects. Each of them has its own logic, argumentation, strengths and weaknesses. Moreover, each of them does not exhaust variety of real manifestations of in-war-existence. 
Appraising the current state of the war in the Eastern Ukraine and formalizing design principles of the "road map" of its solving, authors state the defining role of informative and communicative factors that influence on possibility (or impossibility) of peace-making. As is known, generals always gear themselves for the previous war, what means that gained experience dominates over different innovations. However, "hybrid war" is not similar to classical military operations with air raids, armored breakthroughs and victorious marches of infantry squads. It is hard to tell exactly up to what kind of war our generals prepared our army, but such scenario was unexpected. "In heads of most part of Ukrainian, - rightly points out Vladimir Gorbach, - representations of war are formed by a pattern of "The Great Patriotic War". And no one would have thought that today we participate in quite different war that has so little common with World War Two. The first string in this war is not fuel or bullets, but political (self)identity of ordinary people. This is the war that primarily conducts in human conscience; everything else is only resources for this combating" [Горбач, 2017].

Hybrid war is combination of convectional, irregular and asymmetrical facilities that include permanent political and ideological conflict manipulations, as well as special operations forces, convectional military forces, intelligence agents, political provocateurs and media agents participation, economic bullying; cyber-attacks; para-military and crime figures, terror cells etc.. "Hybrid war" weaponry consists of political propaganda and campaign of disinformation, acts of sabotage and terrorism, economic controls, subversive activities of secret services on enemy territory and curvature of informational space technologies.

Leaders of Russian Federation not without reason chose hybrid form of civilizational expansion, because in Russian society bitter feeling of national wound in response to defeat in Cold War, breakup of the Soviet Union and loss of superstate status is still present. Wary of explicit military opposition with NATO, Russia performs hybrid attacks against the East divergently, successfully using soft spots of western democracies. Kremlin is not satisfied with the global order that formed at the dawn of the $21^{\text {st }}$ century; that is why Kremlin aims at destruction of this order, plunging in chaos, trying to remold the structure of international relations to more profitable conditions with purpose to advance own globalist agendas.

The first victims of hybrid aggression were ex-USSR countries that were close neighbors of Russian Federation, firstly, Georgia and Ukraine. While so-called "08.08.08" war was predominantly "common" military operation of armed power, unfold by Kremlin hostile actions against Ukraine had strongly pronounced hybrid nature. The purpose was to destroy (or at the least to significantly reduce) defensive capabilities of the state system by way of wide use of initiated protest moods, intervention of "informational virus" in value-based and axiological component of mass consciousness, elimination, corrupt practice discrediting of military and political leadership of the country. Approbation of the newest forms of warfighting took place in Crimea and in the Eastern Ukraine, but Ukrainians suffered from perceptible informational pressure from side of Russian mass media even before.

Massive informative and propaganda campaign was directed not only at Ukrainians, but also at Russians, in this case mind control was called for solution of several problems: Russian consolidation around governmentfavored elites, in this case, around Putin guidance; people mobilization to stand up for victorious country values, and even military struggle for such values; formation of new "enemy image" on the basis of mentioned values and conviction of necessity of fighting with this enemy and achieving victory (as fathers and grandfathers in the 1945); blackening of ideological opponents in Ukraine by virtue of labels sticking, attributing with characteristics which they at the truth do not have; mobilization of "fifth column" in Ukraine, fomenting of the conflict, that theretofore was waiting under the layer of ash from seventy years ago, in Ukrainian society with help of discursive weapon; in view of the above said getting forceful social control levers both in Russian Federation and in the most part of the former Soviet Union, achievement of predictable social processes, and then, safety precautions for Russian political space.

Culmination of any kind of conflict is armed standoff, the warfare. In military conflict, proliferation of violence right up to displacement, isolation and murders of unwanted are is observed. During the war, government machine uses all resources available aimed to force the opponent to preferred way of behavior [Додонова, 2015]. Set in motion throughout the conflict "war machine" works on its proper logic that discords with the principles of humanism and often - common sense. Infinite chain of violent acts happens gradually, in them it is hard to define measure of justice, differ actions of party to the conflict motivated with honor, patriotism, revenge, will to power or simply sadistic propensities. High technology intensiveness of modern armed power, very rapid military entanglement of lead geopolitical actors, mobility and logistics, mass media and communication media - these and many other factors significantly level out capabilities of momentary win by means of surprise attack and do not ensure strategic priority.

Assessment of conflict management prospects is based on dominating of "war party" or "party of peace" in the attitude of Ukrainian society in general and the attitude across the population of occupied by Russian Federation troops regions in particular. Associated "subject of peace" demands comprehensive support. It is necessary to detect scattered segments of social forces interested in establishment of strong peace and encourage their activity. With a foundation of authority of so-called "thought leaders", for example, famous representatives of the Church, business, intellectuals, volunteering activities, Soldiers' Mothers Committees, academic figures and cultural figures it is needed to determine and implement civil society interests.

On the institutional level, implementation of civil dialogue and formation of social consensus on reintegration of post-settlement territories would be promoted with creation by Verkhovna Rada of Ukraine full-featured Ad Hoc Committee on questions of isolated districts of the Donetsk and Lugansk regions, unimpaired operation of State Agency for reconstruction of isolated districts of the Donetsk and Lugansk regions in concert with the Committee, involvement of representative of local government, leading civil figures and expert community in working groups.

Authors regard that argumentation of dialogue supporters is more efficient. On the one hand, discursive administration deprives the opponent of his favorable instrumentality. Specification of full-sized warfare area as "ATO zone" is linked with it. In such a way government attempts to transform the problem and transfer it to favorable conceptual area.

War in the Eastern Ukraine, as any other modern armed conflict, does not have merely military options. Crucial moment when military resolution could be possible has been passed. At present, it is obvious that entire use of military force for the conflict management is meaningless. In society of Ukraine realizing of presence of not only military way of victory or defeat, but also way of reasoned communication is formed. It is to be noted that necessary 
conditions of this are forming very slowly. Near-zero capacity of international peace-making discourse make military methods non-competitive.

Establishment of peace on the territory of occupied districts of the Donetsk and Lugansk regions is possible by means of implementation of agreed to Russian Federation "road map". Discursive element of peace promotion in social, economic, political and humanitarian spheres could be possible after demilitarization of the region, withdrawing all Russian arms, instituting control on east borders of Ukraine [Додонов, 2018]. Road mapping makes a connection between vision, strategy and object development plan, it arranges fundamental steps of this process in time on the principle of "past-presentfuture". "Road maps" allow looking through the most probable scenarios and their potential efficiency, risks, as well as choosing the best way of development. Road mapping is based on gathering of experimental information about the system, what allows forecasting of possible options of its future state. As a result of it comes plan-scenario of object development with taking into account alternative routes and possible "pointing up" potential "pinch points".

Any "road map" is a plan of sequent actions that push the system closer to its purpose. Authors tried to formalize algorithm with separation of stages of the Eastern Ukraine conflict resolution.

Stage 1. Localization of conflict area and cessation of hostilities.

First step that should be immediately done during resolution of a conflict is staying of bloodshed. Until today people in the East of Ukraine still die - military personnel, civilians and hired guns. Despite Minsk agreements of cessation of fire and withdrawing all heavy armament, days in ATO zone rarely go without dead, the more so - without wounded. Both sides do not keep agreements; however, cessation of fire act still is necessary condition of effectiveness of further actions provided by "road map". Consequently, localization of conflict area, cessation of fire, withdrawing all heavy armament, creating of security areas become guarantees of further voluntary and cooperated providing with de-escalation of opposition and demilitarization of region by parties to a conflict.

Stage 2. Political stabilization of the region.

The aim of suggested "road map" is reintegration of occupied districts of the Donetsk and Lugansk regions into the political space of Ukraine. It intends destruction of oligarchic and nomenclative patterns, consolidation and encouragement of segment of society that can become a social base of reforms and foundation of reintegrated Donbas reconstruction. Democratic mechanisms suppose appreciation of expression of the will of the people at every given question. There are several different options of reintegration development. Negative development option for Ukrainian society lies in holding a referendum on territory of Donetsk and Lugansk regions concerning the following question: if people in occupied districts want to be a part of Ukraine. After that Ukraine should rebuild relationships with these eastern regions. It is the worst option which presupposes imposing on "the Troic horse". In other words, after Ukrainian formal control reconstitution in there regions in practice all repainted structures of socalled "republics" would exist. Except that politically fringe figures may be removed [Советник президента..., 2015].

Among Ukrainian intellectuals the thought prevails that political solving of the conflict in the Eastern Ukraine would be possible only upon conditions of successful reforming of all Ukrainian society. This option assumes consideration of occupied territories in terms of nationwide social organism where isolated districts of the Donetsk and Lugansk regions "sickness" appears as overreaction to the unhealthy trends of the last-named. Second option suggest holding of an election on occupied territories under the law of Ukraine and under Ukrainian control. However, it is clear that formed in recent years political proclivities of region inhabitants would lead to choice of "painted puppets or puppeteers who led Donbas earlier and practically resulted in present disaster", in other words, old nomenclative and criminal authorities.

The third and the best for Ukraine option suggest "political cleanup" of region and postponing elections for some years. It means that police operation after fulfillment of Minsk agreements should be held and peacemaker should be inducted with purpose of political cleanup, which includes criminal penalties and restriction on civil rights of separatism followers. In this case it is possible to deprive such people of civil rights, who showed non-acceptance of Ukrainian nationhood, that is not just an opposition to some kind of parties, Ukrainian leaders or ideologies, but disclosed exactly non-acceptance of Ukrainian nationhood. In Constitution it is made clear that citizens have to respect the nationhood, sovereignty, territorial integrity. Carrying out systemic reforms in the region would make possible to return to election questions.

Stage 3. Humanitarian rehabilitation.

This stage unlike the first stage, which partially translated into reality, and the second stage, which is for several nearest years, has no limitations in time. Humanitarian component is considered necessary because allows to establish trust-based relationship with locals and create common value-based and sense bearing horizon for further shared activities on reestablishment of peaceful life. While setting out to this stage it is necessary to consider that people of occupied districts of the Donetsk and Lugansk regions greatly differentiated and decomposed, thereby can not be conceived as integral. Ih. Tyshkevych [Тышкевич, 2015] in his article reasonably separates four categories of the Eastern Ukraine people depending on their conflict behavior.

The first category consists of people who endorsed and still endorse attempting of reformation of Ukraine and have tolerant attitude to Ukrainian nationhood. At most they left rebel region and moved to other regions of Ukraine. Usually they have strong skills of cross-cultural communication independent to education level. "Typical example is football fans. One of leaders said the key phrase some time ado "fans traveled around country, saw how people were living elsewhere and, naturally, supported the Maidan". There is no need to work with this group, except for looking among them for future government for the region" [Tышкевич, 2015].

The second category consists of internally displaced persons who ran away from the horrors of war. "Many of them broke away from their small worlds for the first time and found themselves in new environment. So, a small part of them withdraw into themselves and live in "castle siege" mode - precisely such people become heroes of angry examples of "bridge-and-tunnel crowd from Donetsk and Lugansk". But there are other people (and they are in majority). They change gradually. They fly under the rules of normal life in new regions. This group needs help with settling-in. They change independently (even though they do in not so fast as wished it to be) [Тышкевич, 2015].

The third category consists of past inhabitants of occupied districts who moved to Russian Federation. Their problem is complicated. From one side, they saw "Russia's space" from within, at first hand made sure that in the 
native country their life was no worse and presenting of good life of "Great Russia" was nothing more that imagination of Solovyov and Kiselyov. From the other side, stereotypes of seeking fortune not in Ukraine, but in Russian Federation, would not disappear, it could even strengthen because of propagation. In case of return there Ukrainians would rebuilt their familiar little world of "Donetsk mental reservation" with great relish.

Finally, the fourth category consists of people who live "on both sides of the fence". They live constantly on territory of isolated districts of the Donetsk and Lugansk regions, are differ with specific worldview and oppose to the idea of reformation of Ukrainian society. In the long view, independently of the results of war, that particular people would be the most troubled for post-settlement world.

In summary of proposed "road map" stages of occupied districts of regions reintegration, it may be affirmed that the key to a problem is in hands of Ukrainian society. Breaking of dysfunction state of social institution of Education, Public morals, Civil society, Justice, Religion, Politics is key factor of creating preventional conditions that would promote growth of not weak in spirit "mass people", but Personality defended from manipulations. To this effect political willpower, which can result in laying down suitable national program of human development, is needed.

\section{Conclusion}

In conclusion, peace in the Eastern Ukraine was destroyed because of combination of internal and external reasons under prevailing circumstances of aggressive impact on mass consciousness from Russian Federation. Ground of its success was created with help of both civilizational processes of turning nations into collection of Ortegian "mass people" and anti-state destructive activities of political Russian agents and domestic policy makers. The last-named activities endure at this present time in unwillingness of reacting with liberation military actions, absence of real reforms in Education, Law, Massmedia, politics and its imitation with hidden sabotage. It promotes to further anomization, nihilization, mental and moral enfeeblement in Ukraine.

Quick and effective countermeasures to anti-state propagation are possible. However, Ukrainian politicum does not influence on country cleanup from invaders and implementation of Counter-manipulation program with a view of retention of national intellectuals in "somnolence" for own parasitizing, benefication, embosoming of selfexaltation and hedonism. Authors realize that the question of practical realization of proposed "road map" is still open because of conflict freeze. In case of disappearance of external reason transition to peace and reintegration of occupied districts could be possible. However, when politic regulation and local election could take place in the course of several months after establishment of constitutional order, humanitarian rehabilitation would linger on decades.

\section{REFERENCES}

Bazaluk, O. 2016a. The Theory of War and Peace. Philosophical thought. No. 6: 28-52 (rus).

Bazaluk, O. 2016. The Philosophy of War and Peace. Humanitarian Bulletin Zaporizhzhya State Engineering Academy. No. 66: 239-250 (rus).

Bazaluk, O. 2016b. Theory of War and Peace. The Geofilosophy of Europe. MFKO Publishing, Kyiv. 246 p. (rus).

Bouthoul, G. 2006. The phenomenon-war: Methods of polemology, Morphology of wars, Their infrastructures (technical, demographic, economic). Payot. Paris, 283 p.

Dodonov, R. 2015. Crisis, War or Conflict - how Correctly to
Call Events in the East of Ukraine? Skhid. No. 2 (134): 107-112. DOI: https://doi.org/10.21847/1728-9343.2015.2(134).40199.

Dodonov, R. 2015a. "Road Map" Solution of the East-Ukrainian Conflict as a Form of Civic Activity. Bulletin of the Donetsk University. Series B. Humanities. Issue 1: 110-120.

Dodonov, R. 2015b. The Process of Pacification in Ukraine: Transdnistrian and Chechen Options. East Ukrainian conflict in the context of global transformation. Vinnitsa, Ukrainian institute of strategies of global development and adaptation, Nilan-LLC: 143-155.

Dodonov, R. 2016. Two Strategies for Resolving the Conflict in the Donbass. Culturological Bulletin. Scientific and Theoretical Yearbook of the Lower Dnieper. Issue 35: $72-79$ (rus).

Dodonov, R. 2016b. World Experience of Post-Conflict Rehabilitation and Restoration in the Context of Events in the East of Ukraine. New paradigm. Issue 129: 15-25.

Dodonov, R. 2018. "Road map" for Donbass - Logic, Variants and Consequences. In: Dodonova V., Dodonov R. Monologues about Donbass. Selected works on the issues of EasternUkrainian conflict. Kyiv: 317-321.

Dodonov, R., Kovalskyi, Hr., Dodonova, V., Kolinko, M. 2017. Polemological Paradigm of Hybrid War Research. Philosophy and Cosmology. Vol. 19: 97-109. Available at: http://ispcjournal.org/ journals/2017-19/DodonovKovalskyiKolinko-_19.pdf (Accessed: 18.09.2018).

Dodonov, R. 2016a. The Conflict in the East of Ukraine in the Mirror of Social and Philosophical Reflection. Vinnytsia. 200 p.

Dodonov, R. 2017. Conflictological and Polemologic Paradigms in the Research of Armed Conflicts of Today. International Internet Conference Future of Secular Western Civilization in Globalization Processes. May 31, 2017. Kyiv-Brussels-Rome. Proceedings of the Conference. Volume I, Part 1: 14-16. Available at: http://ispcjournal.org/journals/2017-19/DodonovKovalskyiKolinko19.pdf (Accessed: 18.09.2018).

Dodonova, V. 2015. Socialist Aberrations of Donbas and Conservative Modernization of Russia. Skhid. no. 2 (134): 151155. DOI: https://doi.org/10.21847/1728-9343.2015.2(134).40318.

Gorbach, V. 2017. Ukrayinci spryjmayut vijnu za shablonom "Velykoyi Vitchyznyanoyi", [online]. Glavkom. Available at: http:// glavcom.ua/columns/gorbach/ukrajinci-spriymayut-viynu-zashablonom-velikoji-vitchiznyanoji-ale-teper-vse-zovsim-poinshomu-404322.html (Accessed: 10.09.2018).

Hurzhy, V. 2017. The mobilization potential of the religiouslymotivated rhetoric of the "Russian world" project during the events that took place in the Donbass in 2014. Philosophical horizons. Issue 38: 120-126.

Hybrid war: in verbo et in praxi: 2017. Vinnytsya. 412 p. (ukr).

Kant, I. 1994. To the Eternal Peace. In: Kant I. Coll.works: in 8 v. Moskow. V. 7: 5-56

Khalikov, R. 2015. Hot Points of the Modern World: Common and Different in Situations around the "Islamic State" and the Selfproclaimed Republics of the Donbas. Skhid. No 2 (134): 51-55. DOI: https://doi.org/10.21847/1728-9343.2015.2(134).40100.

Kovalskyi, Hr. 2016. Conflict VS War: The Fight for Information Concepts. Gilea. Issue 113: 274-277. Available at: http:// nbuv.gov.ua/UJRN/gileya_2016_113_72 (Accessed: 14.09.2018).

Kovalskyi, Hr. 2017. Axiological Plane of External Factors of Information Confrontation in Ukraine. Intercultural Communication. No. 1: 5-14. Available at: http://cejsh.icm.edu.pl/cejsh/element/ bwmeta1.element. desklight-044bfee4-75eb-46a6-811e594f99e2a706 (Accessed: 11.09.2018).

Kovalskyi, Hr. 2018a. The Concept of Peace in the Light of the War in Eastern Ukraine. Skhid. no 2 (154): 107-109. DOI: https:// doi.org/10.21847/1728-9343.2018.2(154).134304.

Kovalskyi, Hr. 2018. Philosophical Concept of Statehood of Ukraine in the Modern Information Space. Intercultural Communication. Vol. 1(4): 133-147. Available at: http://cejsh.icm.edu.pl/ cejsh/element/bwmeta1 .element.desklight-9a2b8398-4c0c-43ac8878-0f 34 d 0 c 4b 455 ? q =c 0d6d 1f 6-8e87-402b-8679b4a504c57519 \$1\&qt=IN PAGE (Accessed: 12.09.2018). 
Lepsky, M. 2016. Peacemaking in the Context of the Hybrid War in Ukraine: the Definition of Peacekeeping Processes, the Time Perspective, Historical Analogies. East-Ukrainian Conflict in the Context of Global Transformations. Issue 2. Kyiv, Ukrainian Institute of Strategies for Global Development and Adaptation: 119-146 (ukr).

Mandragelia, V. 2003. Causes and Nature of Wars (Armed Conflicts): Philosophical and Sociological Analysis. Kyiv: European University. 569 p. (ukr).

Popovych, M. 2005. Chervone stolittya. Kyiv, 888 p. (ukr).

Sovetnik prezidenta Vladimir Gorbulin: 5 scenariev dlja Ukrainy, [online]. 2015. DailyNews.kz. Available at: http://www.dailynews.kz (Accessed: 10.09.2018).

Stockvish, O., Korolenko, V. 2015. "Crimean Insult": a Myth, its Instrumentalization and Geopolitical Projections. Skhid. no. 2(134): 146-150. DOI: https://doi.org/10.21847/1728-9343.2015.2(134).40317.

Struhatskyi, V. 2016. Aggressive technological influence on the mass consciousness against the background of the EastUkrainian conflict. Soil preparation and first myths. Skhid. no. 3 (143): 93-100. DOI: https://doi.org/10.21847/1728-9343.2016.3(143).74859.
Struhatskyi, V. 2016a. Aggressive technological influence on the mass consciousness against the background of the EastUkrainian conflict. Mythology of the militaristic phase. Skhid. no. 4 (144): 92-100. DOI: https://doi.org/10.21847/17289343.2016.4(144).78100.

Struhatskyi, V. 2017. Prospects for political rehabilitation and aspects of retaliation. Post-militarial phase of the hybrid war. Skhid. no. 2 (148): 105-112. DOI: https://doi.org/10.21847/17289343.2017.2(148).102822.

Struhatskyi, V. 2018. Conceptual Miscalculations of Aggressive Myth-Making. Skhid, no. 2(154): 111-118. DOl: https://doi.org/ 10.21847/1728-9343.2018.2(154).132979.

Struhatskyi, V. 2018a. Manipulating practices against the background of hybrid warfare. Philosophical analysis. Khalikov $R$. Publisher, Kyiv, 166 p. (ukr).

Theories of War and Peace (1998). International Security Readers. Edited by Michael E. Brown. MIT Press. 604 p.

Tyshkevych, Ig. 2015. Rossija uhodit s Donbassa. Chto dal'she delat' Ukraine? [online]. Hvylya. Available at: http://hvylya.net/ analytics/politics/rossiya-uhodit-s-donbassa-chto-dalshe-delatukraine.html (Accessed: 10.10.2018).

Дулєбова Ірина,

доктор філософії, дочент кафедри русистики та східноєвропейських досліджень, філософський факультет Університет ім. Коменського, Братислава, Словаччина

Ковальський Григорій,

кандидат філософських наук, доцент,

Донецький нащіональний університет імені Василя Стуса, м. Вінниия, Украӥна

Додонова Віра,

доктор філософських наук, професор,

Київський університет імені Бориса Грінченка, Украӥна

Білецький Віталій,

кандидат філософських наук, дочент,

Донещький національний університет імені Василя Стуса, м. Вінниия, Украӥна

\section{ВІЙНА ТА МИР: ШЛЯХИ ДО МИРУ В ВІЙНІ НА СХОДІ УКРАЇНИ}

Стаття написана за результатами виконання науково-дослідного проекту "Соціально-фрілософрська рефрлексія шляхів вирішення конфлікту на Сході України" (№ держреєстрації: 0116U002518) і присвячена філософському осмисленню проблеми миру на Сході України. Висвітлено розкриття поняття "війна" та "мир" в історіографії з позицій методології теорії (не)насильства, конфліктології, паксології, полемології, геофілософії тощо. Стверджується, що задля досягнення миру слід від початку використовувати методологію і термінологію паксології як теорії миру, а не полемології як теорії війни. Розкрито специфіку гібридної війни як комбінації конвенційних, іррегулярних, асиметричних засобів, що включають постійну маніпуляцію політичним та ідеологічним конфліктом, а також залучення сил спеціальних операцій та регулярної армії, агентів розвідки, політичних провокаторів, представників медіа, економічний шантаж; кібератаки; пара-військові, терористичні і кримінальні елементи тощо. Продемонстровано гібридні форми встановлення деформованих світоглядних орієнтирів, підміни смислів і формування спотвореної соціокультурної реальності, на тлі яких розгортався конфллікт на Сході України. Сформульовано алгоритм вирішення східноукраїнського конфлікту, запропоновано шляхи подолання ендогенних та екзогенних кризових явищ на Сході України у вигляді "дорожньої карти". Дорожнє картування ув'язує між собою бачення, стратегію і план, вибудовує в часі основні кроки цього процесу за принципом "минуле-сьогодення-майбутнє". У межах "дорожньої карти" виокремлено необхідні кроки подолання конфлікту, а саме: етап локалізації зони конфлікту і припинення вогню; етап політичної стабілізації регіону; етап гуманітарної реабілітації. Оцінка перспектив подолання конфрлікту ґрунтується на домінуванні "партії війни" або "партії миру", в настроях українського соціуму в цілому і серед населення неконтрольованих територій зокрема. Асоційований "суб'єкт миру" вимагає всебічної підтримки держави та громадянського суспільства.

Ключові слова: теорія миру; паксологія; теорія війни; полемологія; інформаційна війна; гібридна війна; війна смислів.

\section{ЛПТРАТУРА}

Базалук О. Теория войны и мира. Геофилософия Европы. Киев: МФКО, 2016. 246 с.

Базалук О. Теория войны и мира. Философская мысль. 2016. № 6. С. 28-52. 250.

Базалук О. Философия войны и мира. Гуманітарний вісник Запорізької державної інженерної академії. 2016. № 66. С. 239-

СХІД № 5 (157) вересень-жовтень 2018 р. 
Гібридна війна: in verbo et in praxi: монографрія. Вінниця, 2017. 412 с.

Горбач В. Українці сприймають війну за шаблоном "Великої Вітчизняної". Главком, 2017. URL: http://glavcom.ua/columns/ gorbach-/ukrajinci-spriymayut-viynu-za-shablonom-velikoji-vitchiznyanoji-ale-teper-vse-zovsim-po-inshomu-404322.html (дата звернення: 10.09.2018).

Гуржи В. Мобілізаційний потенціал релігійно-мотивованої риторики проекту "Русскій мір" під час подій, які відбулися в Донбасі в 2014 році. Філософрські обрії. 2017. Вип. 38. С. 120-126.

Додонов Р. "Дорожня карта" для Донбасу - логіка, варіанти і наслідки. Додонова В.І., Додонов Р.О. Монологи про Донбас. Вибрані праці з проблематики східноукраїнського конфлікту. Київ: ФОП Халіков Р.Х., 2018. С. 317-321.

Додонов Р. Две стратегии разрешения конфликта на Донбассе. Культурологічний вісник. Науково-теоретичний щорічник Нижньої Наддніпрянщини. 2016. Вип. 35. С. 72-79.

Додонов Р. Конфолікт на Сході України у дзеркалі соціально-філософфської рефрлексії: монографрія. Вінниця: ГЛОБУС ПРЕС, 2016. 200 c.

Додонов Р. Криза, війна чи конфлікт - як коректно називати події на Сході України? Схід. 2015. № 2(134). С. 107-112. DOI: https://doi.org/10.21847/1728-9343.2015.2(134).40199.

Додонов Р. Світовий досвід постконфрліктної реабілітації та замирення в контексті подій на Сході України. Нова парадигма. 2016. Вип. 129. С. $15-25$

Додонов Р. "Дорожня карта" вирішення східноукраїнського конфрлікту як форма громадянської активності. Вісник Донецького університету. Серія Б. Гуманітарні науки. 2015. Вип. 1. С. 110-120.

Додонова В. Соціалістичні аберації Донбасу і консервативна модернізація Росії. Cхід. 2015. № 2 (134). C. 151-155. DOI: https://doi.org/10.21847/1728-9343.2015.2(134).40318.

Кант И. К вечному миру. Кант И. Соч.: в 8 m. М., 1994. Т. 7. С. 5-56.

Ковальський Г. Аксіологічна площина зовнішніх чинників інформаційного протистояння в Україні. Intercultural Communication. 2017. № 1: 5-14. URL: http://cejsh.icm.edu.pl/cejsh/element/bwmeta1.element.desklight-044bfee4-75eb-46a6-811e-594f99e2a706 (дата звернення: 11.09.2018).

Ковальський Г. Конфрлікт VS війна: боротьба інформаційних концептів. Гілея. 2016. Вип. 113: 274-277. URL: http://nbuv.gov.ua/ UJRN/gileya 201611372 (дата звернення 14.09.2018).

Ковальський Г. Концепція миру в світлі війни на сході України. Схід. 2018. № 2(154). С. 107-109. DOI: https://doi.org/10.21847/ 1728-9343.2018.2(154).134304

Ковальський Г. Філософська концепція державності України в сучасному інформаційному просторі. Intercultural Communication. 2018. № 1 (4). C. 133-147. URL: http://cejsh.icm.edu.pl/cejsh/element/bwmeta1.element.desklight-9a2b8398-4c0c-43ac8878-0f34d0c4b455?q=c0d6d1f6-8e87-402b-8679-b4a504c57519\$1\&qt=IN_PAGE (дата звернення: 12.09.2018).

Лепський М. Миротворення в умовах гібридної війни в Україні: визначення миротворчих процесів, часова перспектива, історичні аналогії. Східноукраїнський конфрлікт в контексті әлобальних трансформацій. Вип. 2. Київ: Український інститут стратегій глобального розвитку і адаптації, 2016. С.119-146.

Мандрагеля В. Причини та характер воєн (збройних конфрліктів): філософрсько-соціологічний аналіз. Київ: Європейський університет, 2003. 569 с.

Попович М. Червоне століття. Київ: АртЕк, 2005. 888 с.

Советник президента Владимир Горбулин: 5 сценариев для Украины. DailyNews.kz. 2015. URL: http://www.dailynews.kz (дата звернення: 10.09.2018).

Стругацький В. Агресорний технологічний вплив на масову свідомість на тлі східноукраїнського конфлікту. Підготовка ґрунту і перші міфи. Cxid. 2016. № 3(143). C. 93-100. DOI: https://doi.org/10.21847/1728-9343.2016.3(143).74859.

Стругацький В. Концептуальні прорахунки агресорної міфотворчості. Схід. 2018. № 2(154). C. 111-118. DOI: https://doi.org/ 10.21847/1728-9343.2018.2(154).132979.

Стругацький В. Перспективи політичної реабілітації та аспекти відплати. Постмілітарна фаза гібридної війни. Схід. 2017. № 2(148). C. 105-112. DOI: https://doi.org/10.21847/1728-9343.2017.2(148).102822.

Стругацький В. Агресорний технологічний вплив на масову свідомість на тлі східноукраїнського конфлікту. Міфологія мілітарної фрази. Схід. 2016. № 4(144). C. 92-100. DOI: https://doi.org/10.21847/1728-9343.2016.4(144).78100.

Стругацький В. Маніпулятивні практики на тлі гібридної війни. Філософський аналіз: монографрія. Київ: ФОП Халіков Р.Х., 2018. 166 c.

Тышкевич И. Россия уходит с Донбасса. Что дальше делать Украине? Хвиля. 2015. URL: http://hvylya.net/analytics/politics/ rossiya-uhodit-s-donbassa-chto-dalshe-delat-ukraine.html (дата звернення: 10.10.2018)

Халіков Р. Гарячі точки сучасного світу: спільне та відмінне в ситуаціях навколо "Ісламської Держави" та самопроголошених республік Донбасу. Схід. 2015. № 2(134). С. 51-55. DOI: https://doi.org/10.21847/1728-9343.2015.2(134).40100.

Штоквиш О., Короленко В. "Кримська образа": міф, його інструменталізація та геополітичні проекції. Схід. 2015. № 2(134).

C. 146-150. DOI: https://doi.org/10.21847/1728-9343.2015.2(134).40317.

Bouthoul, G. 2006. Le phénomène-guerre: Méthodes de la polémologie, Morphologie des guerres, Leurs infrastructures (technique, démographique, économique). Paris: Payot, $283 p$.

Brown, Michael E. (ed.) Theories of War and Peace. International Security Readers. MIT Press, 1998. $604 \mathrm{p}$

Dodonov R. The process of pacification in Ukraine: Transdnistrian and Chechen options. East Ukrainian conflict in the context of global transformation. Vinnitsa, Ukrainian institute of strategies of global development and adaptation, Nilan-LLC, 2015. C. 143-155.

Dodonov R., Kovalskyi Hr., Dodonova V., Kolinko, M. Polemological Paradigm of Hybrid War Research. Philosophy and Cosmology. 2017. Vol. 19: 97-109. URL: http://ispcjournal.org/journals/2017-19/DodonovKovalskyiKolinko_19.pdf (дата звернення 18.09.2018).

Dodonov R. Conflictological and polemologic paradigms in the research of armed conflicts of today. International Internet Conference Future of Secular Western Civilization in Globalization Processes. May 31, 2017. Kyiv-Brussels-Rome. Proceedings of the Conference. Volume I, Part 1: 14-16. URL: https://uisgda.com/assets/files/zbirnik-konferencii(1).pdf (дата звернення: 13.09.2018).

(C) Dulebova Irina, Kovalskyi Hryhorii, Dodonova Vira, Biletsky Vitaliy

Надійшла до редакції 15.10.2018

СХІД № 5 (157) вересень-жовтень 2018 р. 